\title{
Diallel cross among fresh market tomato inbreeding lines
}

Lívia M de Souza ${ }^{1}$; Maria Elisa AGZ Paterniani ${ }^{1}$; Paulo César T de Melo² ${ }^{2}$ Arlete MT de Melo ${ }^{*}$

${ }^{1}$ IAC-APTA, Centro de Horticultura, C. Postal 28, 13012-970 Campinas-SP; liviamoura31@gmail.com; elisa@iac.sp.gov.br; arlete@iac. sp.gov.br (*corresponding author) ${ }^{2}$ USP-ESALQ, Depto. Prod. Vegetal, C. Postal 9, 13418-900 Piracicaba-SP; pctmelo@esalq.usp.br

\begin{abstract}
The general combining ability (GCA), specific combining ability (SCA), and heterosis were studied in a complete diallel cross among fresh market tomato breeding lines with reciprocal excluded. Fifteen genotypes (five parents and ten hybrids) were tested using a randomized complete block design, with three replications, and the experiments were conducted in Itatiba, São Paulo state, Brazil, in $2005 / 06$. The yield components evaluated were fruit yield per plant (FP), fruit number per plant (FN), average fruit weight (FW); cluster number per plant $(\mathrm{CN})$; fruit number per cluster $(\mathrm{FC})$, fruit wall thickness (FT) and number of locules per fruit (NL). Fruit quality components evaluated were total soluble solids (SS); total titratable acidity (TA); SS/TA ratio, fruit length (FL); fruit width (WI); length to width ratio (FL/WI). The data for each trait was first subjected to analysis of variance. Griffing's method 2, model 1 was employed to estimate the general (GCA) and specific (SCA) combining abilities. Parental and hybrid data for each trait were used to estimate of midparent heterosis. For plant fruit yield, IAC-2 was the best parental line with the highest GCA followed by IAC-4 and IAC-1 lines. The hybrids IAC-1 x IAC-2, IAC-1 x IAC-4 and IAC- 2 x IAC-4 showed the highest effects of SCA. High heterotic responses were found for fruit yield and plant fruit number with values up to $49.72 \%$ and $47.19 \%$, respectively. The best hybrids for fruit yield and plant fruit number were IAC-1 x IAC-2, IAC-1 x IAC-4 and IAC-2 x IAC-5, for fruit yield and plant fruit number, the main yield components.
\end{abstract}

Keywords: Solanum lycopersicum, yield components, fruit quality, combining ability, heterosis, plant breeding.

\section{RESUMO}

Cruzamentos dialélicos entre genótipos de tomate de mesa

Esse trabalho objetivou estimar a capacidade geral de combinação (GCA), capacidade específica de combinação (SCA) e heterose em um cruzamento dialélico completo entre linhagens de tomate, excluindo os recíprocos. Os 15 tratamentos, constituídos por cinco genitores e dez híbridos, foram testados no delineamento em blocos casualizados completos em Itatiba (SP), em 2005/06. Foram avaliados os componentes da produção: produção $(\mathrm{FP})$, número $(\mathrm{FN})$ e peso médio do fruto $(\mathrm{FW})$; número de inflorescências por planta $(\mathrm{CN})$; número de frutos por inflorescência $(\mathrm{FC})$, expessura de parede do fruto (FT) e número de lóculos por fruto $(\mathrm{NL})$; e componentes de qualidade de fruto: sólidos solúveis totais (SS); acidez titulável total (TA); relação entre SS e TA; comprimento de fruto (FL); largura de fruto (WI); relação comprimento/largura (FL/WI). As análises estatísticas foram realizadas segundo o método de análise dialélica de Griffing (método 2, modelo 1). A heterose foi calculada em relação à média dos parentais. Para produção de frutos por planta, o parental que se destacou com maior CGC foram IAC-2, seguido de IAC-4 e IAC-1. Os híbridos IAC-1 x IAC-2 e IAC-2 x IAC-4 apresentaram os maiores valores na estimativa dos efeitos da CEC. Estimaram-se valores elevados de heterose dos híbridos em relação à média dos parentais para a produção de frutos e número de frutos por planta de até $49,72 \%$ e 47,19\%, respectivamente. Os híbridos IAC-1 x IAC-2, IAC-1 x IAC-4 e IAC-2 x IAC-5 destacaram-se como as combinações mais promissoras para produção de frutos e número de frutos por planta, que são os principais componentes da produção.

Palavras-chave: Solanum lycopersicum, componentes da produção, qualidade de fruto, capacidade de combinação, heterose, melhoramento.

\section{(Recebido para publicação em 3 de novembro de 2010; aceito em 28 de maio de 2012) (Received on November 3, 2010; accepted on May 28, 2012)}

\begin{abstract}
A grostatistics include Brazil among the ten major tomato producers in the world. In 2010, the growing area reached 66 thousands ha, resulting in a total yield of about 4.2 millions $\mathrm{t}$ and an average yield of $64.7 \mathrm{t} \mathrm{ha}^{-1}$. It is estimated that 2.0 millions $t$ or about $60 \%$ of the total tomato yield were marketed as fresh fruit and the remaining $40 \%$ were used as processed tomatoes (FAOSTAT, 2011).

The tomato (Solanum lycopersicum) belongs to the Solanaceae family. Because it is a species that has a low cross pollination frequency, it shows a high degree of homozygosity, and its
\end{abstract}

populations, in general, do not show significant diversity. Then, germplasm introduction from different sources is an essential strategy in breeding programs to broaden the genetic base of the species. The phenomenon of heterosis in hybrid combinations has been extensively utilized in agriculture and constitutes an effective method for increasing agricultural yield (Paterniani, 1974). Genetic analysis provides a guide line for the evaluation of relative breeding potential of the parents or identify best combiners in crops (Weerasingh et al., 2004; Sulodhani et al., 2005) which could be utilized either to exploit heterosis in $F_{1}$ or the accumulation of fixable genes to develop new varieties.

The genetic study of agronomic traits is important in the evaluation of the genetic potential of the genitors, for the purpose of obtaining better descendents and increasing breeding methods efficiency (Tavares et al., 1999). In tomatoes, the identification of heterotic combinations and promising crosses by diallel analysis are very practical, since the technique of controlled crosses, albeit laborious, is easily performed and with efficiency (Melo, 1987). The general combining ability (GCA) is a measure of the 
relative behavior of a line in a series of crosses and is associated with additive genetic effects. The specific combining ability (SCA) represents the deviation, for improvement or not, of a particular hybrid combination, based on the GCA mean of the genitors. It is a result of the effects of dominance, epistasis and various types of gene interactions (Griffing, 1956). However, the crossing of two divergent genitors with high GCA does not result in an outstand hybrid due mainly to the fact that non unidirectional dominance is involved in the control of the traits. The magnitude of the variation in GCA and SCA does not depend only on gene effects, but also on gene structures of the genitors involved (Vencovsky \& Barriga, 1992).

The estimate of the combining effect of a cultivar with itself $\left(\hat{\mathrm{s}}_{\mathrm{ii}}\right)$ is important for indicating the direction of the deviations in dominance. If the estimate is negative, the deviations are predominantly positive, and as a consequence, show positive heterosis. However, if $\hat{\mathrm{s}}_{\mathrm{ii}}$ is positive, heterosis will be negative. The magnitude of $\hat{\mathrm{s}}_{\mathrm{ii}}$, in turn, is an indication of the genetic divergence of the parental $i$ in relation to the mean of the other parentals of the diallel (Cruz et al., 2004).

Heterosis is the mean value of the behavior of the hybrid in relation to the mean of its genitors, with regard to one or more characteristics. The estimates of specific combining ability are directly proportional to heterosis, since the mean of the hybrids can be determined from the sum of the general mean of the effects of GCA and SCA.

Diallel analysis has been widely used as a tool to identify hybrid combinations of interest for tomato breeding (Estrada-Salazar, 1984; Melo, 1987; Martinez et al., 1989; Braz, 1992, Padua et al., 2010, Maciel et al., 2011). The quality of the fruits refers to the set of physical attributes, sensory and chemical composition. This information is important not only to meet consumer demands, but also by allowing the genetic selection of new cultivars, selection of optimum production practices appropriate to the post harvest handling (Chitarra \& Chitarra, 1990).
The aims of this work were to determine the GCA, SCA and heterosis in a diallel cross (Griffing's method 2, model 1) among five tomato genotypes related to fruit yield and quality components.

\section{MATERIAL AND METHODS}

Five tomato lines belonging to IAC Tomato Germplasm Collection were used in this study, and all ten possible $\mathrm{F}_{1}$ hybrids among them, excluding reciprocals. The five parentals of $S$. lycopersicum (IAC-1, IAC-2, IAC-3, IAC-4, IAC-5), the ten hybrids and a control (commercial hybrid Débora, Sakata Seeds) were tested using a randomized complete block design with three replications. The experiments were carried out in December-January $2005 / 2006$ in a greenhouse at the Syngenta Seeds Experimental Station, located in Itatiba County, São Paulo state. Each experimental plot contained six plants, and the data were obtained from each one. The yield components evaluated were: fruit yield per plant (FP), fruit number per plant $(\mathrm{FN})$, average fruit weight (FW); cluster number per plant $(\mathrm{CN})$; fruit number per cluster (FC), fruit wall thickness (FT) and number of locules per fruit (NL). These evaluations were performed in all plants of each parcel, at the point of mature fruits in intervals of 10-15 days, during all the production period, totaling a period of 58 days. In all evaluations the marketable (appropriate fruits for consumption) fruits were counted and weighed. For fruit quality components we evaluated the total soluble solids (SS), measured with table refractometer (Carvalho et al., 1990); total titratable acidity (TA), in accordance with the method of Chitarra \& Chitarra (1990); SS/TA ratio, fruit length (FL); fruit width (WI); length to width ratio (FL/ WI). The quality components were evaluated using five random samplings from each parcel in intervals of 10-15 days.

The data were obtained from individual plants and the analysis were based on means of plots, and had been submitted to the analysis of variance and comparison of averages to the level of 5 and $1 \%$ of probability for the test of Tukey. The analysis of combining ability were performed according to Griffing's method 2, model 1 (fixed effects for genotypes), which included the parental cultivars along with n(n-1) $/ 2 \mathrm{~F}_{1}$ hybrids, excluding reciprocals (Griffing, 1956). The Genes Statistical Program (Cruz et al., 2004) was used for data analysis. The heterosis values for the 10 hybrids were calculated in relation to the mean of the genitors and expressed in percentages.

\section{RESULTS AND DISCUSSION}

A preliminary analysis of variance detected significant differences, according to the $\mathrm{F}$ test, in relation to all the traits examined, demonstrating the existence of genetic variability among the lines utilized in the diallel cross.

The quadratic components of SCA were higher than those for GCA in relation to all traits, indicating that gene interactions and genetic structure of the populations studied favor the manifestation of non additive genetic effects of these traits. Some findings were reported by Melo (1987) for the traits FP, FN and FW, where nonadditive genetic effects predominated, and for the trait $\mathrm{CN}$, the result was conflicting, because additive genetic effects predominated. Meanwhile, nonadditive genetic effects were found by Martinez et al. (1989) for the traits FP, FW and FN.

For the trait FP, the superior genitors for GCA were IAC-2, IAC-4 and IAC-1 (Table 1). In relation to $\mathrm{FC}$, the parental line IAC-2 showed a greater estimate of general combining ability $(0.375)$, followed by IAC-1 $(0.140)$ and IAC-4 (0.011). This trait is associated negatively with FW, which can be observed comparing the values obtained by lines IAC- 1 and IAC-3, where the IAC-2 showed the highest positive value for $\mathrm{FC}$ and the lowest negative value for FW (-0.002); the line IAC-3 behaved in the opposite manner showing a negative GCA for FC (-0.073) and positive value for $\mathrm{FW}(0.005)$, with exception of the genitors IAC-4 and IAC-5. Studying diallel crosses between lines of the Santa Cruz group, Resende 
Table 1. Estimates of GCA (gi) effects for thirteen traits of five tomato lines, and standard error (SE) of the effects of two different parentals (estimativas dos efeitos da CGC (gi) para treze caracteres de cinco linhagens de tomate, e erros padrão (EP) dos efeitos de dois parentais diferentes). Itatiba, IAC, 2006.

\begin{tabular}{|c|c|c|c|c|c|c|c|}
\hline \multirow{2}{*}{ Trait $^{1}$} & \multicolumn{5}{|c|}{ Genitor } & \multirow{2}{*}{$\mathbf{D P} \mathrm{g}_{(\mathrm{i})}$} & \multirow{2}{*}{$\mathbf{D P}_{(\text {(gi-gj) }}$} \\
\hline & IAC-1 $g_{(1)}$ & IAC-2 $g_{(2)}$ & IAC-3 $g_{(3)}$ & IAC-4 $g_{(4)}$ & IAC-5 $g_{(5)}$ & & \\
\hline $\mathrm{FP}\left(\mathrm{kg} \mathrm{pl}^{-1}\right)$ & 0.103 & 0.278 & 0.081 & 0.243 & -0.705 & 0.152 & 0.240 \\
\hline $\mathrm{FN}\left(\mathrm{n}^{\mathrm{o}}\right)$ & 2.795 & 4.171 & -0.652 & 0.710 & -7.025 & 1.214 & 1.919 \\
\hline FW (g) & -0.006 & -0.002 & 0.005 & 0.005 & -0.002 & 0.002 & 0.003 \\
\hline $\mathrm{CN}\left(\mathrm{n}^{\circ}\right)$ & 0.377 & 0.413 & 0.025 & 0.167 & -0.983 & 0.162 & 0.256 \\
\hline $\mathrm{FC}\left(\mathrm{n}^{\circ}\right)$ & 0.140 & 0.375 & -0.073 & 0.011 & -0.453 & 0.113 & 0.178 \\
\hline $\mathrm{NL}\left(\mathrm{n}^{\circ}\right)$ & -0.469 & 0.015 & 0.214 & 0.158 & 0.081 & 0.029 & 0.046 \\
\hline $\mathrm{FL}(\mathrm{cm})$ & 0.339 & 0.191 & -0.162 & 0.055 & -0.423 & 0.019 & 0.030 \\
\hline WI (cm) & -0.269 & -0.142 & 0.201 & 0.314 & -0.103 & 0.014 & 0.023 \\
\hline FL/WI & 0.111 & 0.059 & -0.060 & -0.064 & -0.046 & 0.001 & 0.002 \\
\hline $\mathrm{FT}(\mathrm{cm})$ & -0.018 & -0.004 & 0.016 & 0.043 & -0.037 & 0.002 & 0.003 \\
\hline $\mathrm{SS}\left({ }^{\circ}\right.$ Brix $)$ & -0.083 & 0.560 & -0.321 & 0.036 & -0.191 & 0.132 & 0.209 \\
\hline TA $(\%)$ & -0.023 & -0.001 & 0.007 & 0.007 & 0.011 & 0.005 & 0.008 \\
\hline $\mathrm{SS} / \mathrm{TA}$ & 1.348 & 1.742 & -1.555 & -0.386 & -1.149 & 0.434 & 0.685 \\
\hline
\end{tabular}

${ }^{1} \mathrm{FP}=$ fruit yield per plant (produtividade de frutos por planta); $\mathrm{FN}=$ fruit number per plant (número de frutos por planta); $\mathrm{FW}=$ fruit average weight (peso médio de frutos); $\mathrm{CN}=$ cluster number per plant (número de cachos por planta); $\mathrm{FC}=$ number of fruits per cluster (número de frutos por cacho); $\mathrm{NL}=$ number of locules per fruit (número de lóculos por fruto); $\mathrm{FL}=$ fruit length (comprimento dos frutos); $\mathrm{WI}=$ fruit width (largura do fruto); FL/WI= FL to WI ratio (relação FL/WI); FT= fruit wall thickness (espessura da parede do fruto); SS= total soluble solids (sólidos solúveis totais); TA= total titratable acidity (acidez total titulável); SS/TA= SS to TA ratio (relação SS/TA).

Table 2. Estimate of SCA $\left(\mathrm{s}_{\mathrm{ii}}\right.$ and $\mathrm{s}_{\mathrm{ij}}$ ) effects for thirteen traits of tomato and standard deviation (SD) among $\mathrm{F}_{1}$ 's with a common genitor ( $\mathrm{s}_{\mathrm{ij}}$ $\mathrm{s}_{\mathrm{ik}}$ ) and between any two $\mathrm{F}_{1}$ ' $\mathrm{s}\left(\mathrm{s}_{\mathrm{ij}}-\mathrm{s}_{\mathrm{k})}\right)$, of the effects of two $\mathrm{F}_{1}$ hybrids with and without a common parental (estimativa dos efeitos da CEC $\left(\mathrm{s}_{\mathrm{ii}}\right.$ e $\left.\mathrm{s}_{\mathrm{ij}}\right)$ para treze caracteres de tomate e desvio-padrão (dp) entre $\mathrm{F}_{1}$ 's com um genitor comum $\left(\mathrm{s}_{\mathrm{ij}}-\mathrm{s}_{\mathrm{ik}}\right)$ e entre dois $\mathrm{F}_{1}$ 's quaisquer $\left(\mathrm{s}_{\mathrm{ij}}-\mathrm{s}_{\mathrm{kl}}\right)$, dos efeitos de dois $\mathrm{F}_{1}$ 's híbridos com e sem parental comum). Itatiba, IAC, 2006.

\begin{tabular}{|c|c|c|c|c|c|c|c|c|c|c|c|c|c|}
\hline \multirow{2}{*}{ Hybrid } & \multicolumn{13}{|c|}{ Trait $^{1}$} \\
\hline & FP & FN & FW & $\mathrm{CN}$ & FC & NL & FL & WI & FL/WI & FT & SS & TA & SS/TA \\
\hline $\mathrm{s}(1,1)$ & -0.643 & -7.703 & 0.002 & -0.770 & -0.531 & 0.182 & -0.083 & -0.396 & 0.091 & -0.001 & 0.762 & -0.007 & 3.723 \\
\hline$s(1,2)$ & 0.843 & 8.391 & 0.008 & 0.825 & 0.513 & -0.102 & 0.166 & 0.507 & -0.057 & 0.054 & -0.380 & 0.020 & -2.851 \\
\hline $\mathrm{s}(1,3)$ & -0.240 & -0.426 & -0.010 & -0.187 & 0.071 & -0.441 & 0.719 & -0.266 & 0.162 & -0.036 & 0.001 & -0.007 & -0.004 \\
\hline$s(1,4)$ & 0.867 & 8.853 & 0.001 & 1.041 & 0.547 & -0.315 & -0.499 & 0.181 & -0.134 & -0.033 & -0.886 & 0.023 & -4.462 \\
\hline$s(1,5)$ & -0.184 & -1.413 & -0.002 & -0.140 & -0.069 & 0.492 & -0.220 & 0.369 & -0.152 & 0.017 & -0.259 & -0.021 & -0.130 \\
\hline $\mathrm{s}(2,2)$ & -0.301 & -3.724 & 0.003 & -1.211 & 0.317 & -0.056 & 0.044 & -0.350 & 0.096 & -0.030 & -0.023 & 0.007 & -0.535 \\
\hline$s(2,3)$ & -1.054 & -7.331 & -0.014 & 0.278 & -1.194 & -0.725 & -0.303 & -0.033 & -0.085 & -0.050 & 0.528 & 0.000 & 1.672 \\
\hline & & 3.377 & -0.00 & 0.635 & 0.021 & 0.131 & 0.220 & -0.046 & 0.049 & 0.023 & 0.601 & 0.010 & 1.683 \\
\hline$s(2,5)$ & 0.351 & 3.011 & 0.003 & 0.685 & 0.026 & 0.808 & -0.171 & 0.271 & -0.100 & 0.033 & -0.702 & -0.044 & 0.566 \\
\hline$s(3,3)$ & 0.823 & 6.261 & 0.009 & -0.234 & 1.074 & -0.123 & -0.050 & -0.306 & 0.033 & 0.100 & -0.760 & -0.007 & -1.791 \\
\hline$s(3,4)$ & -0.840 & -6.800 & -0.011 & -0.237 & -0.920 & 0.602 & -0.227 & 0.011 & -0.062 & -0.097 & 0.882 & 0.013 & 2.121 \\
\hline $\mathrm{s}(3,5)$ & 0.489 & 2.034 & 0.016 & 0.613 & -0.106 & 0.810 & -0.089 & 0.899 & -0.081 & -0.017 & 0.110 & 0.009 & -0.207 \\
\hline $\mathrm{s}(4,4)$ & -0.053 & -1.631 & 0.009 & -1.020 & 0.516 & -0.142 & 0.386 & -0.002 & 0.112 & 0.076 & -0.375 & -0.017 & -0.278 \\
\hline$s(4,5)$ & -0.384 & -2.167 & -0.004 & 0.601 & -0.680 & -0.135 & -0.266 & -0.144 & -0.077 & -0.044 & 0.152 & -0.011 & 1.215 \\
\hline $\mathrm{s}(5,5)$ & -0.136 & -0.733 & -0.007 & -0.880 & 0.414 & -0.988 & 0.373 & -0.697 & 0.205 & 0.006 & 0.350 & 0.034 & -0.722 \\
\hline & 0.588 & 4.702 & 0.007 & 0.628 & 0.436 & 0.113 & 0.073 & 0.056 & 0.005 & 0.008 & 0.513 & 0.019 & 1.679 \\
\hline $\operatorname{DP}\left(s_{i j}-s_{k l}\right)$ & 0.537 & 4.292 & 0.006 & 0.573 & 0.398 & 0.103 & 0.066 & 0.051 & 0.005 & 0.007 & 0.468 & 0.017 & 1.533 \\
\hline
\end{tabular}

${ }^{1} \mathrm{FP}=$ fruit yield per plant $\left(\mathrm{kg} \mathrm{pl}^{-1}\right)$ (produção de frutos por planta); $\mathrm{FN}=$ fruit number per plant (número de frutos por planta); $\mathrm{FW}=$ fruit average weight $(\mathrm{g})$ (peso médio de frutos); $\mathrm{CN}=$ cluster number per plant (número de cachos por planta); $\mathrm{FC}=$ number of fruits per cluster (número de frutos por cacho); $\mathrm{NL}=$ number of locules per fruit (número de lóculos por fruto); $\mathrm{FL}=$ fruit length (cm) (comprimento do fruto); $\mathrm{WI}=$ fruit width $(\mathrm{cm})$ (largura do fruto); FL/WI= FL to WI ratio (relação FL/WI); FT= fruit wall thickness (cm) (espessura da parede do fruto); $\mathrm{SS}=$ total soluble solids $\left({ }^{\circ} \mathrm{Brix}\right)$ (sólidos solúveis totais); $\mathrm{TA}=$ total titratable acidity (\%) (acidez titulável total); $\mathrm{SS} / \mathrm{TA}=\mathrm{SS}$ to $\mathrm{TA}$ ratio (relação SS/TA). 
Table 3. Estimate of heterosis effect in relation to the mean of the parentals for thirteen fruit traits of tomato (estimativa do efeito de heterose em relação à média dos parentais para treze caracteres de fruto de tomate). Itatiba, IAC, 2006.

\begin{tabular}{|c|c|c|c|c|c|c|c|c|c|c|c|c|c|}
\hline \multirow{2}{*}{ Hybrid } & \multicolumn{13}{|c|}{ Trait $^{1}$} \\
\hline & FP & FN & FW & $\mathbf{C N}$ & FC & NL & FL & WI & FL/WI & FT & SS & TA & SS/TA \\
\hline IAC-1 x IAC-2 & 49.716 & 45.405 & 5.882 & 28.293 & 12.757 & -6.776 & 2.564 & 16.236 & -11.111 & 7.778 & -13.274 & 7.407 & -20.942 \\
\hline IAC-1 x IAC-3 & -10.963 & $0.944-$ & 15.789 & 4.835 & -4.175 & -18.077 & 11.519 & 1.469 & 8.333 & -8.629 & 0.000 & 0.000 & -5.607 \\
\hline IAC-1 x IAC-4 & 44.424 & 47.190 & -5.263 & 30.886 & 12.078 & -13.215 & -8.966 & 6.281 & -19.028 & -7.000 & -21.818 & 13.208 & -32.172 \\
\hline IAC-1 x IAC-5 & 11.748 & 13.129 & 0.000 & 13.211 & -0.245 & 43.980 & -5.395 & 17.313 & -23.077 & 1.695 & -16.028 & -11.864 & -8.936 \\
\hline IAC-2 x IAC-3 & -39.195 & $-24.855-$ & 20.000 & $15.798-$ & -34.679 & -21.417 & -4.458 & 4.971 & -13.043 & -8.629 & 19.785 & 0.000 & 18.214 \\
\hline IAC- $2 \times$ IAC-4 & 20.779 & $18.913-$ & 10.000 & 28.783 & -7.517 & 7.931 & 0.070 & 2.097 & -4.641 & 0.000 & 15.385 & 5.085 & 11.950 \\
\hline IAC-2 x IAC-5 & 27.273 & 21.189 & 5.882 & 34.600 & -7.173 & 55.417 & -5.689 & 14.627 & -20.000 & 5.085 & -16.214 & -20.000 & 7.240 \\
\hline IAC-3 x IAC-4 & -35.559 & $-28.321-$ & 18.182 & $6.311-$ & -33.076 & 23.980 & -5.839 & 2.513 & -13.043 & -17.051 & 36.709 & 8.475 & 23.258 \\
\hline IAC-3 x IAC-5 & 5.906 & -2.932 & 15.789 & $22.941-$ & -18.201 & 53.216 & -3.981 & 24.138 & -18.182 & -7.216 & 7.711 & -1.538 & 8.347 \\
\hline IAC-4 x IAC-5 & -13.303 & -4.414 & -5.263 & 31.959 - & -25.587 & 17.200 & -9.605 & 3.380 & -20.705 & -8.629 & 3.560 & -6.250 & 11.824 \\
\hline
\end{tabular}

${ }^{1} \mathrm{FP}=$ fruit yield per plant $\left(\mathrm{kg} \mathrm{pl}^{-1}\right)$ (produtividade de frutos por planta); $\mathrm{FN}=$ fruit number per plant (número de frutos por planta); $\mathrm{FW}=$ fruit average weight (g) (peso médio de frutos); $\mathrm{CN}=$ cluster number per plant (número de cachos por planta); $\mathrm{FC}=$ number of fruits per cluster (número de frutos por cacho); $\mathrm{NL}=$ number of locules per fruit (número de lóculos por fruto); $\mathrm{FL}=$ fruit length (cm) (comprimento do fruto); $\mathrm{WI}=$ fruit width $(\mathrm{cm})$ (largura do fruto); FL/WI= FL to WI ratio (relação FL/WI); FT= fruit wall thickness (cm) (espessura da parede do fruto); $\mathrm{SS}=$ total soluble solids ( ${ }^{\circ} \mathrm{Brix}$ ) (sólidos solúveis totais); $\mathrm{TA}=$ total titratable acidity (\%) (acidez titulável total); $\mathrm{SS} / \mathrm{TA}=$ SS to TA ratio (relação SS/TA).

et al. (2000) found similar results for the traits FC and FW. Some studies also report a greater participation of additive effects on expression of the average fruit weight, such as Amaral Júnior et al. (1999), Garg et al. (2008), Nizio et al. (2008), and Padua et al. (2010). Haydar et al. (2007) observed that fruit weight exerted high positive and direct effect on fruit yield per plant.

Fruit wall thickness (FT), associated with traits of FW and size of fruits is undoubtedly, a yield component of great importance in tomato crops, because this is directly linked to fruit quality and yield. For this trait the lines IAC3 and IAC-4 had positive values for GCA of 0.016 and 0.043 , respectively, contributing to the increase in wall thickness of the fruits in their crosses (Table 1). According to Marim et al. (2009), the endocarp thickness, width of the central axis of fruits and the number of loci are related to the firmness, being one of the most important attributes associated with fruit quality, both for fresh consumption and for industrial use, being crucial for the storage period.

Regarding to the level of SS, the line IAC-2 (0.560) stood out showing a positive GCA, followed by the line IAC-4 (0.036). IAC-3 demonstrated a lower value of GCA (-0.321), making a negative contribution to the level of SS in the hybrids in which it participated. However, for the trait TA, the genitor IAC-5 showed a greater positive estimate, followed by IAC-3 and IAC-4. The parental line IAC-1 (-0.023) showed a negative GCA, being desirable when the objective is to obtain fruits with less acidity (Table 1). Similar results were obtained by Bhatt et al. (2001) who also found significant values of GCA for these traits.

The results of SCA for FP showed that the hybrids IAC-1 x IAC-2 and IAC- $1 \times$ IAC-4 stood out with values of $0.843 \mathrm{~kg}$ plant $^{-1}$ and $0.867 \mathrm{~kg}_{\text {plant }}{ }^{-1}$, respectively, where the genitors IAC-1, IAC- 2 and IAC-4 involved in these two hybrids, were considered good general combiners, with positive estimates of GCA and negative $\hat{\mathrm{S}}_{\mathrm{ii}}$, which contributed to positive heterosis (Table 2). The resulting hybrids of crosses IAC- $2 \mathrm{x}$ IAC-5 and IAC- $3 \times$ IAC-5 also showed positive values of SCA. However, these hybrids are not being considered for use on a commercial scale, because they did not show a fruit size in line with market demand.

The increased yield in tomato crops as a result of a heterotic effect has been reported previously by various authors, although with differences in magnitude (Melo, 1987; Braz, 1992).

The combination IAC- 1 x IAC-4 showed the maximal effect of SCA for FN, followed by IAC-1 x IAC-2. It can be seen that the crosses with positive effects of SCA included at least one genitor with good GCA for the charater FN. The hybrid IAC-3 x IAC- 5 behaved in a contrary manner, differing from that expected, because its genitors IAC-3 and IAC-5 had strong negative values for GCA (Table 1), while in the hybrid combination, a positive effect of SCA was 2.034 (Table 2); the heterosis value for this hybrid combination was negative (Table 3).

For the SCA refering to $\mathrm{FC}$, the hybrids IAC-1 x IAC-4 and IAC-1 x IAC- 2 stood out with positive values of 0.547 and 0.513 , respectively. For the trait $\mathrm{CN}$, the hybrids IAC- $1 \mathrm{x}$ IAC4 (1.041), IAC-1 x IAC-2 (0.825), IAC- $2 \times$ IAC-5 (0.685) and IAC-2 $x$ IAC-4 (0.635) showed positive SCA, while the hybrid IAC-3 $x$ IAC$4(-0.237)$ showed the most negative value (Table 2). The traits $\mathrm{CN}$ and FC are subcomponents of $\mathrm{FN}$, which in turn is one of the main components of yield (FP). Furthermore, there is a limited association between $\mathrm{CN}$ and $\mathrm{FC}$ with FW. As a result, a genotypic increment for $\mathrm{FW}$ is associated with a genotypic decrease for FN. This behavior is explained by Estrada-Salazar (1984). It has been reported that number of fruits 
per plant is positively correlated with yield per plant (Rani et al., 2008; Tiwari \& Upadhyay et al., 2011).

For FP and FN all evaluated genitors showed a negative $\hat{\mathrm{s}}_{\mathrm{ii}}$ value except line IAC-3 which showed a positive value of 0.823 and 6.261 (Table 2). These results reflect the genetic divergence among the studied lines and agree with results found for heterosis. The negative signs and high absolute values of $\hat{\mathrm{s}}_{\mathrm{ii}}$ for the traits $\mathrm{CN}$ and WI of all genitors indicated that the genetic divergence among them was high and that heterosis in their hybrids was always positive (Table 2).

High heterosis values were determined for the hybrids in relation to the mean of the genitors for the traits FP (up to 49.72\%) and FN (up to $47.19 \%$ ), which are the main yield components (Table 3). The hybrids IAC$1 \mathrm{x}$ IAC-2, IAC-1 $\mathrm{x}$ IAC-4 and IAC- $2 \mathrm{x}$ IAC-5 stood out as the most promising combinations for the component FP. For FW, the hybrids that showed positive heterosis were IAC-3 x IAC-5 (15.79\%) and IAC- $1 \times$ IAC-2 and IAC-2 $x$ IAC$5(5.88 \%)$. One explanation for the absence of heterosis in the majority of the crosses, for FW, is directly related to the mode of inheritance for fruit size. Maciel et al. (2011) showed a predominance of additive effects in controlling the traits. There was no significant specific heterosis of the evaluated crosses.

For FT, heterosis was low and varied from $-17.05 \%$ to $7.78 \%$, where the hybrids IAC-1 x IAC-2 (7.78\%) and IAC-2 x IAC-5 (5.08\%) had the highest levels (Table 3). FT is a trait of growing importance as it is directly tied to fruit quality and yield, because fruits with thicker walls are heavier, have better post-harvest conservation due to less marked withering, and greater firmness of fruit.

Heterotic effects were observed varying between $-21.82 \%$ and $36.71 \%$ for SS (Table 3), where these results do not coincide with those reported by Amaral Junior et al. (1999), and Bhatt et al. (2001), who concluded that the low values of heterosis obtained are probably associated with the existing low variability of the plants utilized as genitors.

In view of the results obtained, it is evident that the lines involved in this diallel study can be explored in breeding programs for the purpose of obtaining new hybrids. The lines IAC-2 and IAC-4 stood out showing a positive GCA for the majority of the examined traits. The combinations IAC-1 x IAC-2, IAC-1 x IAC-4 and IAC- $2 \times$ IAC-4 stood out with the best performance among the genotypes evaluated. The exception is the line IAC-5 which is not indicated for breeding programs when the objective is fruit yield, because it shows negative values of GCA for all these traits. However, this line is nematode resistant, and it can be included in breeding programs aiming to obtain resistant cultivars to this pathogen. The hybrids exhibited very high values of heterosis in relation to the mean of the genitors for the main yield components, total fruit weight and number of fruits per plant.

\section{ACKNOWLEDGEMENTS}

To CAPES, for a scholarship awarded to the first author. To Syngenta Seeds Ltda., for providing the facilities to carry out this research. To Dr. Cassia Regina Limonta Carvalho, for her guidance in performing the chemical analysis and for making her phytochemistry laboratory available.

\section{REFERENCES}

AMARAL JUNIOR AT; CASALI VWD; CRUZ CD; FINGER FL. 1999. Inferências genéticas na produção e qualidade de tomateiro sob cruzamento dialélico. Pesquisa Agropecuária Brasileira 34: 1407-1416.

BHATT RP; BISWAS VR; KUMAR N. 2001. Heterosis, combining ability and genetics for vitamin $C$, total soluble solids and yield in tomato (Lycopersicon esculentum) at 1700 $\mathrm{m}$ altitude. Journal of Agricultural Science 137: 71-75.

BRAZ LT. 1992. Estudos da heterose e da capacidade combinatória visando produção de frutos e sementes de tomate (Lycopersicon esculentum Mill.). Jaboticabal: FCAV-UNESP. $116 \mathrm{p}$ (Tese doutorado).

CARVALHO CRL; MANTOVANI DM; CARVALHO PRN; MORAES RM. 1990. Análises químicas de alimentos (Manual Técnico). Campinas: Biblioteca do ITAL.

CHITARRA MI; CHITARRA AB. Pós-colheita de frutos e hortaliças: fisiologia e manuseio.
Lavras: ESAL/FAEPE, 1990, 320p.

CRUZ CD; REGAZZI AJ; CARNEIRO PCS. 2004. Modelos biométricos aplicados ao melhoramento genético. 3. ed. Viçosa: UFV. $480 \mathrm{p}$.

ESTRADA-SALAZAR EI. 1984. Evaluación de cruzamientos dialélicos en tomate (Lycopersicon esculentum Mill.), Bogotá: Universidad de Columbia. 109p (Tese mestrado).

FAOSTAT. 201129 de dezembro. Database results. Disponível em: http://faostat.fao.org/.

GARG N; CHEEMA DS; DHATT AS. 2008. Genetics of yield, quality and shelf life characteristics in tomato under normal and late planting conditions. Euphytica 159: 275-288.

GRIFFING B. 1956. Concept of general and specific ability in relation to diallel crossing systems. Australian Journal of Biological Sciences 9: 462-93.

HAYDAR A; MANDAL MA; AHMED MB; HANNAN MM; KARIM R. 2007. Studies on genetic variability and interrelationship among different traits in tomato (Lycopersicon esculentum Mill.). Middle-East Journal of Scientific Research 2: 139-142.

MACIEL GM; MALUF WR; SILVA VF. 2011. Heterose e capacidade combinatória de linhagens de tomateiro ricas em acilaçúcares. Ciência e Agrotecnologia 34: 1161-1167.

MARIM BG; SILVA DJ; CARNEIRO PCS; MIRANDA CV; MATTEDI AP; CALIMAN FRB. 2009. Variabilidade genética e importância relativa de caracteres em acessos de germoplasma de tomateiro. Pesquisa Agropecuára Brasileira 44: 1283-1289.

MARTINEZ PBA; SANINT PR; VALLEJO CABRERA FA. 1989. Análisis de la heterosis y de la habilidade combinatoria entre diferentes cultivares de tomate, Lycopersicon esculentum Mill., a partir de um cruzamento dialelico. Acta Agronômica 39: 24-33.

MELO PCT. 1987. Heterose e capacidade combinatória em um cruzamento dialélico parcial entre seis cultivares de tomate (Lycopersicon esculentum Mill.). Piracicaba: ESALQ-USP. 107 p (Tese doutorado).

NIZIO DAC; MALUF WR; FIGUEIRA AR; NOGUEIRA DW; SILVA VF; GONÇALVES NETO AC. 2008. Caracterização de genótipos de tomateiro resistentes a begomovírus por marcador molecular co-dominante ligado ao gene Ty-1. Pesquisa Agropecuária Brasileira 43: 1699-1705.

PÁDUA TRP; GOMES LAA; MALUF WR; CARVALHO FILHO JLS; GONÇALVES NETO AC; ANDRADE MC. 2010. Capacidade combinatória de híbridos de tomateiro de crescimento determinado, resistentes a begomovírus e tospovírus. Pesquisa Agropecuária Brasileira 45: 818825.

PATERNIANI E. 1974. Estudos recentes sobre heterose. São Paulo: Fundação Cargill, 36p. (Boletim, 1).

RANI CI; VEERARAGAVATHATHAM D; SANJUTHA S. 2008. Studies on correlation and path coefficient analysis on yield attributes in root knot nematode resistant $F_{1}$ hybrids of tomato. Journal of Applied Sciences Research 
4: 287-295.

RESENDE LV; MALUF WR; RESENDE JTV; GOMES LAA. 2000. Capacidade combinatória de linhagens de tomateiro do tipo Santa Cruz com diferentes níveis e controles genéticos de resistência a tospovírus. Ciência e Agrotecnologia 24: 549-559.

SULODHANI DE; SINGH NB, BIJAYA DA, SINGH NG; LAISHRAM GM. 2005. Gene action for fruit yield and its components in tomato (Lycopersicon esculentum Mill.). Indian J. Genet 65: 221-222.

TAVARES M; MELO AMT; SCIVITTARO WB. 1999. Efeitos diretos e indiretos e correlações canônicas para caracteres relacionados com a produção de pimentão. Bragantia 58: 41-47.

TIWARI JK; UPADHYAY D. 2011. Correlation and path-coefficient studies in tomato (Lycopersicon esculentum Mill.) Research Journal of Agricultural Sciences 2: 63-68.
VENCOVSKY R; BARRIGA P. 1992. Genética biométrica no fitomelhoramento. Ribeirão Preto: Sociedade Brasileira de Genética. 496p. WEERASINGH OR; PERERA ALT, COSTA WAJM; JINADASE DM; VISHNUKARTHASINGHAM R. 2004. Production of tomato hybrids for dry zone conditions of Sri Lanka using combining ability analysis, heterosis and DNA testing procedure. Trop. Agric. Res. 16: 79-90. 